\title{
ANTYKONCEPCJA W POGLĄDACH I DOŚWIADCZENIACH WSPÓŁCZESNEJ MŁODZIEŻY
}

\author{
Magdalena GiŁKa \\ gilka.magdalena@wp.pl
}

(9) $\odot \Theta \Theta$

\section{WSTĘP}

Termin antykoncepcja pochodzi z języka łacińskiego i w dosłownym tłumaczeniu oznacza: ,pprzeciw poczęciu"1 . Głównym celem stosowania antykoncepcji jest zapobieżenie zapłodnieniu dzięki korzystaniu z określonego typu (lub typów) środków².

Różnorodne metody antykoncepcyjne znane są od stuleci, a ich używanie należy do powszechnych zjawisk prawie w każdej kulturze. W starożytnej Grecji i Rzymie kobiety, które nie chciały, aby w ich łonie poczęło się dziecko, stosowały płyny przyspieszające menstruację lub oklejały szyjkę macicy preparatem wykonanym z żywicy ${ }^{3}$. W Indiach zaś jedna z receptur zalecała kobietom, aby spożywały przez dwa tygodnie duże ilości trzyletniej melasy, dzięki czemu do końca życia miały one pozostać bezdzietne. Natomiast w Chinach do najczęstszych metod antykoncepcyjnych należało połykanie żywych kijanek ${ }^{4}$.

I choć sposobów na zmniejszenie prawdopodobieństwa poczęcia dziecka było w historii wiele, to należy pamiętać, że dopiero wynalezienie tabletki antykoncepcyjnej w latach sześćdziesiątych XX wieku spowodowało, że młodzi ludzie zupełnie zakwestionowali dotychczas dominujące w społeczeństwie zasady, które od lat regulowały ludzką seksualność. Od tego czasu zwiększył się zakres wolności wyboru oraz możliwości kontrolowania przez ludzi ich życia seksualnego. Tabletka antykoncepcyjna stanowiła swoiste narzędzie, za pomocą którego można było zmniejszyć ryzyko zajścia w ciążę. Dzięki jej stosowaniu ludzie w znacznej mierze przestali obawiać się ryzyka związanego z poczęciem dziecka6. W literaturze zjawisko to określa się mianem „seksualnego wyzwolenia lat 60-tych”, które w następnej dekadzie przekształciło się w „seksualny hedonizm”. Powróciła wówczas idea tzw. „,seksu rekreacyjnego", którego celem była jedynie przyjemność sama w sobie?

Dla sposobu pojmowania miłości przez współczesnych nastolatków oraz kształtowania się ich seksualności, a co za tym idzie, także poglądów i doświadczeń związanych z antykoncepcja, duże znaczenie miały również lata 80- te XX wieku, czyli okres tzw. „seksualnego szoku”, który został wywołany przez epidemię AIDS. Skutkiem tego zjawiska okazały się m.in. dwie sprzeczne tendencje, jakie zaczęły panować w społeczeństwie w latach 90- tych XX wieku. Z jednej strony dominowała "pogon”" za przyjemnością seksualna, z drugiej zaś - „ucieczka” przed AIDS. Według niektórych badaczy „walka" ta trwa do dnia dzisiejszego, a we współczesnym społeczeństwie konsumpcji występuje swoisty „taniec wokół seksu"8. Jednakże bez względu na to, na którą stronę przechyla się szala zwycięstwa,

\footnotetext{
1 Stownik wyrazów obcych, http://www.bryk.pl/s\%C5\%82owniki/s\%C5\%82ownik_wyraz\%C3\%B3w_obcych

/241039-antykoncepcja_anty_\%C5\%82ac_conceptio_pocz\%C4\%99cie.html, 25.11.2010.

Encyklopedia popularna PWN, Warszawa 1982, s. 36.

J. Hołówka, Etyka w działaniu, Warszawa 2001, s. 183

A. Szarewski, J. Guillebaud, Wszystko o antykoncepcji, Kraków 1997, s. 26.

Z. Melosik, Tożsamość, ciało i władza w kulturze instant, Kraków 2010, s. 177.

6 O. Grabowska, Pop miłość - społeczno-kulturowe konstrukcje tożsamości seksualnej wspótczesnych nastolatków, [w:] A.

Gromkowska (red.), Kultura popularna i (re)konstrukcje tożsamości, Poznań-Leszno 2007, s. 310.

7 Z. Melosik, Tożsamość..., dz. cyt., s. 177.

8 Tamże, s. 178.
} 
w każdej z wymienionych sytuacji (w większej lub mniejszej części) młodzi ludzie korzystają ze środków antykoncepcyjnych. Dlatego też podejmując badania empiryczne, postanowiono zbadać poglądy i doświadczenia młodych ludzi związane z antykoncepcją.

Pragnę jednak zaznaczyć, że wyniki badań dotyczących antykoncepcii, które zostały zawarte $\mathrm{w}$ tym artykule, stanowiąjedynie część znacznie obszerniejszych badań, $\mathrm{w}$ których weryfikowano między innymi aktywność seksualną współczesnej młodzieży.

\section{Cele badań}

Sformułowane cele badań obejmują następujące zagadnienia:

- Dokonać charakterystyki aktywności seksualnej młodych ludzi z uwzględnieniem: częstości podejmowania aktywności seksualnej; rodzaju partnerów seksualnych; podawanych przez młodzież przyczyn rozpoczynania bądź rezygnacji z aktywności seksualnej.

- Przedstawić doświadczenia współczesnej młodzieży związane z antykoncepcją.

- Wskazać źródła wiedzy dotyczącej antykoncepcji, z jakich korzysta współczesna młodzież.

- Zbadać opinie młodych ludzi na temat antykoncepcji.

\section{MATERIAE I METODY}

Dobór badanej próby był celowy. Badania przeprowadziłam w dwóch poznańskich szkołach licealnych. Uczestniczyło w nich 54 uczniów, przy czym większość spośród nich stanowiły kobiety (było ich ok. 63\%). Najwięcej respondentów miało ukończone 19 lat. Warto również dodać, że zdecydowana większość, bo aż $87 \%$ osób na stałe mieszka w mieście.

Zastosowaną przeze mnie metodą był sondaż diagnostyczny, techniką ankieta, natomiast narzędziem badawczym kwestionariusz ankiety.

\section{WYNIKI I DYSKUSJA}

Jak wynika z moich badań, prawie połowa współczesnych nastolatków jest aktywna seksualnie. Większość z nich współżyje ze stałym partnerem, choć co trzecia osoba przyznaje, że podjęła stosunki seksualne z dwiema różnymi osobami. Należy także podkreślić, że ok. 11\% młodych ludzi podaje, iż w swoim życiu mieli oni trzech lub więcej partnerów seksualnych. Ponadto, nie wszyscy osiemnastoi dziewiętnastolatkowie twierdza, że osoby, z którymi nawiązują oni kontakty seksualne, są im znane. Można domyślać się, że podjęcie współżycia seksualnego z nieznanymi osobami zazwyczaj wiąże się ze stosowaniem przez młodziez środków antykoncepcyjnych.

Adolescenci nie potrafią wskazać konkretnego momentu, w którym należy przejśc inicjację seksualną. Według najczęściej podawanej przez nich „rady”, współżycie seksualne powinno się rozpocząć, „,kiedy jest się na to gotowym”. Jednakże nikt spośród nich dokładnie nie dookreślit, co w zasadzie oznacza wspomniane „bycie gotowym”. Czy mieli oni na myśli gotowość emocjonalna, fizyczna, ekonomiczna, prawną czy może jeszcze inną? Niezależnie jednak od jej rodzaju, należy podkreślić, że z uwagi na wydłużający się w dzisiejszych czasach okres nauki, coraz więcej młodych ludzi rozpoczyna aktywność seksualną pomimo braku ekonomicznej gotowości na przyjęcie potencjalnie poczętego dziecka jako efektu podjętego współżycia. Należy zatem przypuszczać, że coraz więcej młodych ludzi korzysta z antykoncepcji.

Co więcej, jak się okazuje, głównymi powodami, dla których współcześni nastolatkowie rozpoczynają wspótżycie seksualne, jest potrzeba zaspokojenia własnej ciekawości, pragnienie sprostania oczekiwaniom narzuconym im przez inne osoby oraz chęć pozbycia się przez nich napięcia seksualnego. Można zatem domyślać się, że tego typu nastawienie sprzyja stosowaniu środków antykoncepcyjnych. 
Ponadto, jak wynika z badań, najczęstszą przyczyna, dla jakiej obecna młodzież rezygnuje z podjęcia współżycia seksualnego, jest obawa przed pojawieniem się niechcianej ciąży. A zatem można przypuszczać, że osoby, które chcą rozpocząć aktywności seksualną - w celu usunięcia najważniejszej przeszkody, jaką ich zdaniem jest ryzyko poczęcia dziecka - sięgnają po wybrane środki antykoncepcyjne.

Warto również zauważyć, że wyniki moich badań dotyczące doświadczeń młodzieży związanych $\mathrm{z}$ antykoncepcją potwierdzają to przypuszczenie. Bowiem okazuje się, że połowa adolescentów korzysta z różnorodnych metod antykoncepcyjnych, co pokrywa się z liczbą osób, które przeszły już inicjację seksualną. Należy więc stwierdzić, że młodzi ludzie, którzy rozpoczęli już współżycie seksualne, stosują metody antykoncepcyjne. Nastolatki przyznaja, że najczęściej sięgają po prezerwatywy oraz pigułki antykoncepcyjne. Ponadto ok. 22\% młodych osób jako metodę antykoncepcyjną wybiera stosunek przerywany, zaś ok. $11 \%$ adolescentów pod kategoria „inne" podało, że stosuje metodę naturalna.

A zatem okazuje się, że adolescenci nie posiadają wystarczającej wiedzy na temat metod antykoncepcyjnych, bowiem niektórzy spośród nich za antykoncepcję uważają metody naturalnego planowania rodziny, a przecież WHO (Światowa Organizacja Zdrowia) sprzeciwia się takiej klasyfikacji. Stosowanie metod naturalnych uznawane jest za swoisty styl życia, który nie jest ukierunkowany na zmniejszanie prawdopodobieństwa zajścia w ciążę czy też zminimalizowania ryzyka zachorowań na choroby przenoszone drogą płciową. Co więcej, nie ingeruje on (jak czynią to metody antykoncepcyjne) w naturalny rytm ludzkiej płodności?.

Brak gruntownej wiedzy młodych ludzi na temat antykoncepcji potwierdzają również wyniki badań dotyczące typów podawanych przez nich metod. Otóż adolescenci w odpowiedzi na pytanie o znane im metody antykoncepcyjne - obok hormonalnych, mechanicznych, chirurgicznych i chemicznych - umieszczali także metody naturalne (naturalnego planowania rodziny).

Analiza poglądów współczesnej młodzieży dotyczących antykoncepcji ukazała, że zdecydowana większość młodych ludzi uważa, iż metody antykoncepcyjne są ",metodami całkowicie zapobiegającymi zajściu w ciążę". Niewiele osób wie, że metody antykoncepcyjne nie dają pewnej gwarancji zabezpieczenia się przed poczęciem dziecka, lecz w mniejszym lub większym stopniu jedynie zmniejszają taką ewentualność. A zatem ponownie zostaje potwierdzona teza, że głównym powodem, dla jakiego adolescenci sięgają po antykoncepcję, jest pragnienie uniknięcia ciąży. Niestety jednak niewiele spośród nastolatków zdaje sobie sprawę, że antykoncepcja tylko zmniejsza prawdopodobieństwo pojawienia się skutków podjętego współżycia seksualnego.

Niski poziom wiedzy młodych ludzi na temat antykoncepcji zmusza do zastanowienia się nad jej źródłami. Otóż, jak się okazuje, ponad połowa młodych ludzi uzyskuje wiadomości z tego zakresu od swoich rówieśników oraz z internetu. Zdecydowanie mniej osób zdobywa potrzebne informacje od specjalistów (np. ginekologów), rodziców czy też nauczycieli. Zdaje się, że zjawisko to wynika z tzw. „przesunięcia socjalizacyjnego", które coraz częściej opisywane jest w literaturze. Polega ono na tym, że tradycyjne instytucje socjalizacji, tj. rodzina, szkoła, Kościół, coraz bardziej tracą na znaczeniu, a ich rolę w sposób niezwykle inwazyjny przejmuja: grupa rówieśnicza, mass media i kultura popularna ${ }^{10}$.

Warto w tym miejscu wspomnieć, że współczesne instytucje socjalizacji najczęściej są nośnikiem tzw. etyki „złotego środka”, która przejawia się w przyjmowaniu postawy określanej mianem „,świecko- liberalnej”. Zgodnie z jej założeniami, celem wspólnego pożycia jest satysfakcja seksualna i szczęście osobiste. Ten model etyki uprawnia antykoncepcję, a co za tym idzie, także przedmałżeńskie obcowanie płciowe. Dozwolona jest swoboda seksualna z wyjątkiem przypad-

$9 \quad$ http://npr.pl//index.php/content/view/320/43/, 25.11.2010.

10 Z. Melosik, Kultura popularna jako czynnik socjalizacji, [w:] Kwieciński Z., Śliwerski B. (red.), Pedagogika: podręcznik akademicki, tom 1, Warszawa 2003, s. 68. 
ków szkodliwości oraz braku dojrzałości w jej korzystaniu ${ }^{11}$.

Poruszając temat związany z antykoncepcja, nie sposób pominąć kwestii związanej z kontrowersjami, jakie w tym zakresie pojawiają się we współczesnym społeczeństwie. Wynikają one z rozbieżności w myśleniu na temat kierunku wychowania seksualnego. Kozakiewicz wyróżnia trzy zasadnicze systemy norm moralnych: wyżej opisaną etykę „złotego środka”, etykę restrykcyjną oraz permisywną ${ }^{12}$. Ta druga podkreśla, że seks jest wartościowy tylko wtedy, gdy jest elementem miłości małżeńskiej i stanowi czynnik prokreacyjny. Wiąże się ona z pojęciem „postawy katolickiej” w odniesieniu do seksualności, co oznacza myślenie oraz postępowanie zgodne z nauką Kościoła katolickiego. Opisując tę moralność seksualną należy ją odnieść do norm w sferze życia małżeńsko- rodzinnego, bowiem na II Soborze Watykańskim została sformułowana doktryna głosząca, że miłość małżeńska i prokreacja powinny być komplementarne, tj. muszą wzajemnie się uzupełniać i warunkować. Co więcej, etyka ta zakłada, że jedynie małżeństwo (zawarte w Kościele) uprawnia partnerów do rozpoczęcia wspótżycia seksualnego i dlatego też wszelkie stosunki przed-i pozamałżeńskie są zakazane ${ }^{13}$.

W ujęciu etyki permisywnej seks jest wartością autonomiczna, wręcz nadrzędną. Stosunki przedmałżeńskie są całkowicie akceptowane, prokreacja nie jest ściśle związana ze współżyciem seksualnym. Stosowanie antykoncepcji stanowi moralny obowiązek i - jak podaje Mikołaj Kozakiewicz - nie zachęca się partnerów seksualnych do posiadania dzieci ${ }^{14}$.

Jednakże, jak wynika z badań, pomimo różnych systemów norm moralnych, które promują lub zakazują stosowanie antykoncepcji, nie ulega wątpliwości, że połowa adolescentów korzysta z wybranych metod antykoncepcyjnych. A zatem w opinii młodych ludzi muszą one posiadać zalety. I rzeczywiście tak jest, bo analiza wyników badań przekonuje, że według nastolatków tzw. „dobrą stroną” antykoncepcji jest przede wszystkim możliwość zapobiegania zajściu w ciążę, mniejsze prawdopodobieństwo zarażenia chorobami przenoszonymi drogą płciową oraz podejmowania współżycia w sposób bezstresowy. Po raz kolejny okazuje się więc, że młodzi ludzie stosują środki antykoncepcyjne przede wszystkim w celu uniknięcia niechcianej ciąży (a dzięki temu także stresu i odpowiedzialności). W związku z tym można domniemywać, że podejmowane przez nich zachowania seksualne są przedwczesne, gdyż partnerzy seksualni nie chcąi/lub nie są w stanie ponieść wszystkich konsekwencji swojego postępowania. Wydaje się, że nastolatki naiwnie wierza, że antykoncepcja uchroni ich przed pejoratywnymi skutkami wynikającymi z podjętego przez nich działania o charakterze seksualnym.

Jednakże, jak powszechnie wiadomo, środki antykoncepcyjne nie są swoistą „przepustką" do lepszego i bezstresowego życia seksualnego. Bowiem nawet dziś, w dobie nowoczesnej technologii, nie opracowano jeszcze idealnej metody antykoncepcyjnej. Doskonałe rozwiązanie antykoncepcyjne powinno zapewnić całkowite zabezpieczenie przed ciąża, nie wywołując jednocześnie zagrożeń o charakterze zdrowotnym w postaci działań ubocznych. Ponadto niezawodna metoda powinna chronić przed chorobami przenoszonymi drogą płciową a jej stosowanie nie powinno wymagać jakiejkolwiek czynności ze strony lekarza i/lub partnerów seksualnych przed stosunkiem czy też w jego trakcie lub po jego zakończeniu ${ }^{15}$. Jak wynika z badań, młodzi ludzie mają świadomość, że stosowanie niektórych środków antykoncepcyjnych pociąga za sobą działania niepożądane. Najczęściej wymieniali oni zagrożenie wystapienia bezpłodności oraz zaburzenia w gospodarce hormonalnej organizmu kobiety. Fakt znajomości przez adolescentów choćby niektórych niebezpieczeństw wynikających ze stosowania

11 K. Sieja, Wiedza o życiu seksualnym człowieka. Wybrane zagadnienia, Koszalin 1998, s. 69.

12 K. Imieliński (red.), Seksuologia społeczna. Zagadnienia psychospołeczne, Warszawa 1997, s. 419.

3 K. Sieja, Wiedza..., dz. cyt., s. 69-70.

14 K. Imieliński (red.), Seksuologia..., dz. cyt., s. 419-420.

15 A. Szarewski, J. Guillebaud, Wszystko..., dz. cyt., s. 11. 
wybranych środków antykoncepcyjnych napawa optymizmem. To dobry znak, gdyż daje nadzieję, że młodzi ludzie nie sięgają w sposób bezmyślny po oferowane im środki antykoncepcyjne.

\section{Podsumowanie}

W jednej ze swoich książek Andrzej Jaczewski postawił następujące pytanie: „Czy [...] dziś erotyzm dostarcza tylko pięknych i radosnych przeżyć?"'16. Niestety wyłaniający się z moich badań obraz poglądów i doświadczeń młodych ludzi związany z antykoncepcją (a co za tym idzie także z ich aktywnością seksualną), wskazuje na konieczność udzielenia negatywnej odpowiedzi, a także postulowania ogromnej potrzeby prowadzenia zajęć dotyczących stosowania określonych metod antykoncepcyjnych. Podczas ich realizacji powinno się uwzględnić: potrzebę obopólnej odpowiedzialności i zgody partnerów na stosowanie określonej metody; szczegółowe informacje o zasadach stosowania poszczególnych metod oraz ich dostępności; prawidłowy zasób słownictwa, a także konieczność konsultacji u lekarza ginekologa ${ }^{17}$. Zdaje się, że nie należy udzielać młodym ludziom trywialnych wyjaśnień na temat tego, skąd się biorą dzieci. Niezależnie od rodzaju etyki seksualnej, kluczowe jest przekazywanie zasobu wiadomości znacznie szerszych i pogłębionych zarówno z pogranicza psychologii, biologii, socjologii oraz patologii. $\mathrm{W}$ przeciwnym razie, młodzi ludzie często w sposób nieświadomy (bo z braku dostatecznej wiedzy) będą krzywdzić siebie oraz innych ${ }^{18}$, co w sposób przyczyno- skutkowy z pewnością pociagnie za sobą szereg reperkusji.

Sądzę, że w trakcie rozmowy edukacyjnej pedagog powinien zrezygnować z roli tzw. władcy oświeconego, który uważa, że przekazuje wychowankom absolutną mądrość, prawdę i wiedzę. Stoi przed nim niebanalne zadanie nawiązania z wychowankami żywej dyskusji, która zaowocuje pogłębieniem świadomości młodych ludzi w zakresie antykoncepcji ${ }^{19}$. Realizacja tego zadania nie należy do łatwych, szczególnie dziś, gdy szkoła i rodzina tracą na znaczeniu w procesie socjalizacji młodego człowieka ${ }^{20}$. Jednakże uważam, że profilaktyczna edukacja seksualna w szkole powinna być jedynie dopetnieniem wiedzy, jaką młodzi ludzi winni uprzednio zdobyć w środowisku rodzinnym od osób najbardziej znaczących, jakimi są rodzice (opiekunowie) ${ }^{21}$.

Pragnę podkreślić, że przekazywanie młodemu pokoleniu wiedzy na temat życia seksualnego (w tym antykoncepcji) jest szczególnie istotnym przedsięwzięciem ze względu na fakt, że współczesna młodzież dorasta i nawiązuje relacje miłości w społeczeństwie konsumpcyjnym, w którym - jak już wspomniałam we wstępie - nieustannie występuje przecież „taniec wokół seksu”22.

\section{Bibliografia}

Boguski J., Kryzys rodziny w świetle koncepcji socjalizacji J. J. Arnetta oraz J. D. Harris, [w:] Kępski Cz. (red.), Opieka i wychowanie w rodzinie, Lublin 2003.

Encyklopedia popularna PWN, Warszawa 1982.

Grabowska O., Pop miłość - społeczno-kulturowe konstrukcje tożsamości seksualnej wspótczesnych nastolatków, [w:] Gromkowska A. (red.), Kultura popularna i (re)konstrukcje tożsamości, Poznań-Leszno 2007.

Gromkowska A. (red.), Kultura popularna i (re)konstrukcje tożsamości, Poznań-Leszno 2007.

Hołówka J., Etyka w działaniu, Warszawa 2001.

6 A. Jaczewski, Kultura seksualna młodzieży, Warszawa 1979, s. 6.

B. Woynarowska, Edukacja zdrowotna: podręcznik akademicki, Warszawa 2007, s. 368.

Tamże, s. 6.

9 Z. Melosik, Kultura..., dz. cyt., s. 91.

${ }^{20}$ Por. Z. Melosik, Kultura..., dz.cyt., s. 91 oraz J. Boguski, Kryzys rodziny w świetle koncepcji socjalizacji J. J. Arentta oraz J. D. Harris, [w:] Cz. Kępski (red.), Opieka i wychowanie w rodzinie, Lublin 2003.

21 B. Woynarowska, Edukacja..., dz. cyt., s. 352.

22 Z. Melosik, Tożsamość..., dz. cyt., s. 178. 
Imieliński K. (red.), Seksuologia społeczna. Zagadnienia psychospołeczne, Warszawa 1997.

Jaczewski A., Kultura seksualna młodzieży, Warszawa 1979.

Kwieciński Z., Śliwerski B. (red.), Pedagogika: podrẹcznik akademicki, t. 1, Warszawa 2003.

Melosik Z., Kultura popularna jako czynnik socjalizacji, [w:] Kwieciński Z., Śliwerski B. (red.), Pedagogika: podręcznik akademicki 1, Warszawa 2003.

Melosik Z., Tożsamość, ciało i władza w kulturze instant, Kraków 2010.

Sieja K., Wiedza o życiu seksualnym człowieka. Wybrane zagadnienia, Koszalin 1998.

Szarewski A., Guillebaud J., Wszystko o antykoncepcji, Kraków 1997.

Woynarowska B., Edukacja zdrowotna: podręcznik akademicki, Warszawa 2007.

\section{Netografia}

Stownik wyrazów obcych, http://www.bryk.pl/s\%C5\%82owniki/s\%C5\%82ownik_wyraz\%C3\%B3w_obcych/241039-antykoncepcja_anty_\%C5\%82ac_conceptio_pocz\%C4\%99cie.html, 25.11.2010.

http://npr.pl//index.php/content/view/320/43/, 25.11.2010.

\section{Słowa kluczowe}

antykoncepcja, aktywność seksualna, młodzież.

\section{STRESZCZENIE}

Autorka artykułu przedstawia wyniki przeprowadzonych przez nią badań, które są częścią obszerniejszych dotyczących między innymi aktywności seksualnej współczesnej młodzieży. Przedmiotem niniejszej pracy uczyniła ona poglądy i doświadczenia młodych ludzi związane z antykoncepcją. W oparciu o udzielone przez adolescentów odpowiedzi, opisuje m.in.: źródła informacji dotyczących metod antykoncepcyjnych, z jakich korzystają nastolatki; sposób rozumienia przez nich pojęcia „,metody antykoncepcyjne"; znane im metody oraz podawane przez nich wady i zalety antykoncepcji. Artykuł zawiera także wyniki dotyczące praktyki stosowania antykoncepcji przez współczesną młodzież.

Analiza przeprowadzonych badań przekonuje, że młodzi ludzie nie mają ugruntowanej wiedzy dotyczącej antykoncepcij, co z całą pewnością wpływa na ich doświadczenia w sferze życia seksualnego. W związku z tym autorka konstruuje wnioski dla pracy wychowawczej w zakresie edukacji seksualnej współczesnej młodzieży.

\section{CONTRACEPTION IN OPINIONS AND EXPERIENCES OF THE MODERN YOUTH}

\section{Keywords \\ Contraception, sexual activity, the youth}

\section{Summary}

The author of this article presents the results of her research, which are a part of a wider investigation on, among others, sexual activity of the modern youth. The subject of this work are opinions and experiences of young people connected to contraception. Based on adolescents' answers the author describes among others sources of information about contraceptive methods used by teenagers, their understanding of the notion "contraceptive methods", methods they are familiar with and advantages and drawbacks of contraception enumerated by the teenagers. The article contains also conclusions linked to the use of contraception by the modern youth.

The analysis of the conducted research proves that young people do not have reliable knowledge about contraception what undoubtedly affects their experiences in their sexual lives. Consequently, the author formulates conclusions for the sake of pedagogic work concerning sexual education of the modern youth. 